\title{
Impact of Renminbi Appreciation on China's Trade Balance: From Empirical Evidence
}

\author{
Wei Guo \\ Department of Credit Management, Guangdong University of Finance, Guangzhou, China \\ Email:602500326@qq.com
}

How to cite this paper: Guo, W. (2017) Impact of Renminbi Appreciation on China's Trade Balance: From Empirical Evidence. American Journal of Industrial and Business Management, 7, 816-831. https://doi.org/10.4236/ajibm.2017.76058

Received: April 27, 2017

Accepted: June 26, 2017

Published: June 29, 2017

Copyright $\odot 2017$ by author and Scientific Research Publishing Inc. This work is licensed under the Creative Commons Attribution International License (CC BY 4.0).

http://creativecommons.org/licenses/by/4.0/ (c) (7) Open Access

\begin{abstract}
By estimating trade balance equation, export equation and import equation, this paper shows empirically that China's trade surplus is not sensitive to the fluctuations in the real effective exchange rate, but the price elasticity has become large and significant in the period from 2005 onwards after the new exchange rate regime was instituted on 21 July, 2005. In the latter case, I found divergent results on ordinary trade and processing trade, i.e. the appreciation in Renminbi has found to reduce ordinary trade balance and increase processing trade balance. In addition, I found the appreciation has larger impact on processing trade (both the processing exports and the processing imports) than it has on ordinary trade.
\end{abstract}

\section{Keywords}

Renminbi Appreciation, Trade Balance, Real Effective Exchange Rate

\section{Introduction}

China, the world's biggest exporter, has maintained large surplus in trade since accession to WTO in 2001. China's largest trade partner, i.e. U.S. has attributed the Chinese trade surplus to its undervalued national currency, which claims that China has gained unfair advantage from trade because of Renminbi undervaluation which leads to trade imbalance. Since July 2005 when a new regime was instituted, for the first time Renminbi is allowed to trade within a wide band of 0.3 per cent per business day. From July 2005 to the end of 2013, the Renminbi's exchange rate against the US dollar has appreciated by over 25 percent in nominal terms. However, the Renminbi appreciation is still deemed to be far from enough to correct global imbalance. The most urgent issue is whether the Renminbi appreciation can be as a tool to reduce China's huge trade surplus, particularly given the size of global imbalance and the pressure applied by Chi- 
na's trade partners. The answer very much depends on whether and to what extent the Renminbi appreciation could reduce China's trade surplus or how effective Renminbi appreciation can be in terms of reducing exports and fostering imports.

The main concern of the paper is: Can the appreciation of the Renminbi reduce China's trade surplus and correct global imbalance? Though the trends of variation for both the trade balance and real effective exchange rate are very clear, it's still difficult for us to draw any conclusion on the relationship between them, addressing this question requires estimates of the impact of Renminbi appreciation on trade balance. In this paper, I construct a vector auto-regression (VAR) model and apply econometric techniques to find empirical evidence for the impact of Renminbi appreciation on China's trade balance using data from March 2000 to March 2012. Furthermore, data from July 2005 onwards are collected as a subsample in the estimation.

I select data from 2000 to 2012 as a full sample in the estimation for the following reason: China's economy has gone through a transformation from a centrally-planned economy to a more market-oriented one since 1978 when President Deng initiated unprecedented reforms that affected China's trade in a great extent. Before that, exports and imports were not responsive to the changes in Renminbi real exchange rate because the Chinese government made plans and specified economic targets for most all types of international trade. Until 2001, since accession to WTO, China has eliminated all nontariff barriers and became more market-oriented, since then, the Chinese volume of exports and imports in trade has been more sensitive to the changes in real exchange rate. As for the subsample, I collect data from July 2005 onward for two reasons: first, Chinese authority has announced a switch from the dollar peg regime to a managed floating exchange rate regime with reference to a basket of currencies based on market since July 2005, to study the period onwards help to identify whether China's trade balance has become responsive to the changes in the exchange rate after the reform of exchange rate regime. Secondly, since July 2005 when a new regime was instituted there has been over $25 \%$ appreciation of the Renminbi-US dollar rate until the end of 2013, the estimation for this very period would provide us useful results on the impact of Renminbi appreciation on trade balance.

In the estimation, I disaggregated trade products into two catalogues, ordinary products and processing products. Specifically, for imports, I distinguish between ordinary imports and the imports used for processing goods to be re-exported. In the same way, I differentiate between ordinary and processing exports. As defined by Garcia-Herrero and Koivu, processing trade is composed of processing exports and processing imports. Processing exports comprises exports of goods for assembly outside China and exports of products assembled using imported components while processing imports is comprised of the imports of components for assembly into exportables [1]. Ordinary trade, refers to final export and import products which are not subject to further processing and not assembled from imported components. Distinguishing the two types of trade 
products helps to provide reasons why some studies have not found a significant relationship between the volume of trade and the value of the exchange rate. The fact is that since processing exports in China's trade comprises exports of goods for assembly outside China and exports of products assembled using imported components, it's not clear what effect that changes in the Renminbi's exchange rate would have on the demand for the assembled products. Specifically, the effect from Renminbi appreciation on the price of the imports which composed of components for assembly into exportables could affect the demand for exports of assembled goods using imported components. Therefore, in the estimation for the impact of exchange rate on trade, the two types of products should be differentiated.

The rest of the paper is organized as follows: Section 2 reviews existing literatures, in which I will discuss the shortage of relevant papers and the innovation of this paper. In section 3, model set up, data used and the methodology in estimating the models will be describe. Empirical findings will be presented in section 4 . Section 5 discusses conclusion and the main limitations of the paper.

\section{Literature Review}

Previous attempts to estimate the effects of Renminbi appreciation on China's trade balance have yielded mixed results for the following reasons: firstly, different methods are used in measuring Chinese trade volume. Since data on Chinese trade prices are not available, proxies are often used in estimations, however, in some papers, Chinese trade shares are applied instead of proxies, the diversity of methods in measuring trade volume leads to mixed results. Secondly, divergence happened in choosing estimation samples. Some estimation samples include the period of China's transformation from a centrally-planned economy to a more market-oriented one while others exclude the transforming period in their estimations. Finally, various empirical methodologies are applied in generating mixed results.

The existing literature can be divided into two main groups. One strand of the relevant literature proves that a real Renminbi exchange appreciation reduce trade balance, either through reducing exports, or by increasing imports, or in both ways. However, the other strand shows very different results, a number of authors find that changes of Renminbi exchange rate have no significant effect on the trade balance or even a positive impact.

Within the first strand, Dees separates China's exports and imports into two categories, processed and original. He finds that Renminbi appreciation has great impact on export and ordinary exports are more price sensitive than processed exports, but in the short-run, international trade is mainly influenced by demand rather than exchange rate [2]. Bénassy-Quéréand Lahrèche-Révil find that changes in exchange rate has greater impact on international trade in China than in middle-Asia, they report that a $10 \%$ real depreciation of Renminbi leads to reduction in China's imports from emerging Asia while increases China's exports to OECD countries [3]. Thorbecke study the impact of changes in 
exchange rate on triangular trading patterns in Asia using a gravity model. His results indicate that a ten percentage of Renminbi appreciation decreases Chinese final exports by nearly $13 \%$. However, the Renminbi appreciation does not have significant impact on imports [4]. Shu and Yip estimate the impact of exchange rate movements on the Chinese economy as a whole and show that Renminbi appreciation can reduce exports via an expenditure-switching effect and contraction effect on aggregate demand [5]. Marquez and Schindler, apply shares of China's exports and imports in world trade instead of the volume of trade to avoid the use of proxies for export and import prices. They find the appreciation of Renminbi has very little impact on China's export and import share of the world by reporting that a ten percentage of Renminbi appreciation would lead to $0.5 \%$ of reduction in China's exports share of world and China's imports share of world by a $0.1 \%$ [6]. John Whalley and Li Wang evaluate the joint impacts of exchange rate appreciation on trade flows and country surpluses using a general equilibrium trade model, result shows that while elasticity dependent, the impacts of Renminbi (RMB) revaluation on the surplus are proportionally larger than on trade flows [7]. Chee-Wooi Hooy, Siong-Hook Law, Tze-Haw Chan studied trade between China and Association of Southeast Asian Nations (ASEAN). They find that the RMB real exchange rate has a significant positive impact on ASEAN total exports to China and that the exports of high-tech and medium-tech finished goods, as well as the parts and components exports, contribute to this effect. Which means Renminbi exchange appreciation reduce trade balance, by increasing imports from ASEAN [8].

Within the other strand, a number of authors find that changes of Renminbi exchange rate have no significant impact on the trade balance or even positive impact. By looking at Chinese exports, Cerra and Saxena try to determine how market signals affect Chinese export supply. Two indexes, the export unit values and the export volumes for Chinese exports, are created and quarterly data from the mid-1980s to 2001 is adopted. In the larger dataset used in this paper, more than 50 percent of total exports is used while having a large portion of commodities data included, on the other hand, about 95 percent of the missing data is from manufacturing industries. In their study, the price elasticity of export supply estimation changes with the reforming process of the export regime, closer periods following reforms would cause market price signals generate an increased response of export supply. Their results also indicate that Renminbi appreciation has actually boosted exports [9]. To investigate China-U.S. trade, Mann and Plück adopt an error correction model which was applied to disaggregate bilateral data. For the testing period from 1980 to 2004, U.S. imports from China shows an extremely high income elasticities, on the contrary, a relatively low income elasticity is created by U.S. exports to China. However, price elasticity estimates are not statistically significant which indicates changes of Renminbi exchange rate have no significant impact on trade [10]. Eckaus studies how exchange rate would effect on exports from China to the US annual export data. Two specifications with different dependent variable are used: the level of 
China's exports to the United States and the share of US imports from China. The results from the specification in terms of shares without proxies shows that statistically, the exchange rates do not have significant effect on China's exports to the US [11]. Cheung et al. adopts dynamic OLS methods, they estimate Chinese trade elasticities, both on a multilateral and bilateral (with the United States) basis and obtain the result that a 10 percent increase of real appreciation of RMB would cause a 46 billion (US \$) reduction in the Chinese trade balance, which is relatively small comparing with the 401 billion (US \$) trade balance in 2006. They find that Renminbi exchange rate changes would not cause significant effects in neither of the two previous methods. US exports to China increases with the appreciation of RMB but China's exports to the US is not affected as the effect of real exchange rate on overall trade flows is relatively small and sometimes goes in the opposite direction [12]. Garcia-Herrero and Koivu examine data over the period, 1995 to 2005, they distinguish processing products and ordinary products in trade pattern. They analyze the price elasticity of imports and exports by estimating bilateral export and import equations, use co-integration techniques to estimate the price elasticity of imports and exports, and short-run and long-run elasticities was separately tested. They find that China's trade balance is sensitive to the fluctuations in the real exchange rate, but the reduction of trade surplus caused by RMB appreciation is limited because China's imports from other Southeast Asia countries are reduced with a real appreciation of RMB [1]. McKinnon also conclude that with the process of financial globalization, appreciate of Renminbi is not sufficient and would not reduce China's trade surplus [13]. Zhaoyong Zhang and Kiyotaka Sato construct and estimate a VAR model to assess how the sensitivity the economic system to the market signal would change during the reform period using quarterly data from Q1 of 1987 to Q4 of 2009. For the world income variable, real GDP series of either the US or OECD countries was adopted as a proxy. They find that China's trade balance is slightly affected by the exchange rate, and largely affected by worldwide demand shock and trade balance shock [14]. Chi Gong \& Zi-Yang Liu applied a VAR model to analyze the effects of RMB exchange rate brought to processing trade, non-processing trade and FDI. They found that the appreciation of RMB could not solve the problem of US trade deficit. It is more likely that the appreciation just can transfer the trade imbalance to other country with US [15].

Overall, the results from existing literature are either too old or have limitations concerning sample, data and empirical techniques. The mixed and confusing results fail to provide convictive evidence for policy conclusions. Firstly, the overall effect of Reminbi appreciation on trade balance have been given less attention while most literatures estimated separately the export and import equation to obtain income and price elasticities. Secondly, most estimation sample includes the period of China's transformation from a centrally-planned economy to a more market-oriented one regardless of the changes in exchange rate regime therefore fail to provide reliable conclusions for the real impact of ex- 
change appreciation on trade. In this paper, I use data from 2000 to 2012 which includes the Renminbi appreciation period and the period since the reform of exchange rate regime (Chinese authority has announced a switch from the dollar peg regime to a managed floating exchange rate regime with reference to a basket of currencies based on market since July 2005), so as to better assess whether a Renminbi appreciation could reduce China's trade surplus and correct global imbalance. In addition, I enrich the analysis by not only estimating export and import equations but also trade balance equation to reveal the overall impact of Renminbi appreciation on trade balance.

\section{Model Set up and Data}

\subsection{Model Set up}

Three important equations are applied in this paper to study the impact of Renminbi (RMB) exchange rate on China's trade balance. Firstly, trade balance equation is estimated to provide us a whole picture on how Renminbi exchange rate affects trade balance. Domestic demand and foreign demand are adopted in the equation as crucial factors which affect trade balance directly, as Garcia-Herrero and Koivu [1], I add foreign direct investment (FDI) as a control variable in the equation. In order to discover in further how does exchange rate influence China's trade balance though export and import, I also estimate export and import equations in attempt to determine the sensitivity of Chinese exports and imports to changes in the Renminbi exchange rate. In the export equation, foreign demand is included to estimate income elasticity for exports while domestic demand is included in the import equation to estimate income elasticity for imports. As Garcia-Herrero and Koivu, FDI is introduced in both export and import equations and value-added tax rebates is added in the export equation as controls [1].

In attempt to discover the effect of Renminbi appreciation on different trade products, I classify the trade products into two categories: ordinary products and processing products as Dees [2]. Specifically, for imports, I distinguish between ordinary imports and the imports used for processing goods to be re-exported. In the same way, I differentiate between processed and ordinary exports. As defined by Garcia-Herrero and Koivu, processing trade is composed of processing exports and processing imports [1]. Processing exports comprises exports of goods for assembly outside China and exports of products assembled using imported components while processing imports is comprised of the imports of components for assembly into exportables. Ordinary trade, refers to final export and import products which are not subject to further processing and not assembled from imported components. All the variables in export and import equations are taken logs for smoothing the series and providing elasticity inference.

Model 1: Trade Balance Equation

$$
\mathrm{LnTBt}=a_{0}+a_{1} \mathrm{LnREERt}+a_{2} \mathrm{LnYt}+a_{3} \mathrm{LnYt}^{*}+a_{4} \mathrm{LnFDI}+\text { error }
$$

${ }^{1}$ The Equations (1), (2), (3) represent original equations estimated in the model. 
LnTBt: trade balance (Ln(Export/import)), specifically, ordinary trade balance and processing trade balance. LnREERt: real effective exchange rate. LnYt: domestic demand. LnYt*: foreign demand. LnFDI: foreign direct investment. Where $a_{1}$ denotes price elasticity of trade balance, measures the impact of exchange rate on trade balance. $a_{2}$ and $a_{3}$ denotes income elasticities, which used to measure the effect of domestic demand and foreign demand on trade balance. The coefficient $a_{4}$ is the elasticity for FDI, it measures the response in trade balance to the change of FDI.

Model 2: Export and Import Equations

$$
\begin{aligned}
\mathrm{LnXt}= & a_{0}+a_{1} \text { LnREERt }+a_{2} \text { LnYt }^{*}+a_{3} \text { LnFDI }+a_{4} \text { LnVATrebate }+ \text { error } \\
& \text { LnMt }=b_{0}+b_{1} \text { LnREERt }+b_{2} \text { LnYt }+b_{3} \text { LnFDI }+ \text { error }
\end{aligned}
$$

In the export equation, LnXt: The volume of China's exports, specifically, the volume of China's ordinary export and processing export. LnREERt: real effective exchange rate. $\mathrm{LnYt}^{*}$ : foreign demand. LnFDI: foreign direct investment. LnVATrebate: value-added tax rebates offered to exporting companies. Where $a_{1}$ is the price elasticity of exports, $a_{2}$ is the income elasticity of exports. $a_{3}, a_{4}$ denotes elasticity for FDI and value-added tax rebates respectively. In the import equation, LnMt: The volume of China's imports, specifically, the volume of China's ordinary import and processing import. LnREERt: real effective exchange rate. LnYt: domestic demand. LnFDI: foreign direct investment. Where $b_{1}$ denotes the price elasticity of imports, $b_{2}$ is the income elasticity of imports. $b_{3}$ is the elasticity for FDI.

\subsection{Data}

For the dependent variables, I have collected data on Chinese exports and imports from March 2000 to March 2012, on a monthly basis includes the Renminbi appreciation period and the period since the reform of exchange rate regime in July, 2005. So as to study the effect of Renminbi exchange rate on China's trade in respect to the new exchange rate regime (Chinese authority has announced a switch from the dollar peg regime to a managed floating exchange rate regime with reference to a basket of currencies based on market since July 2005), I include a sub-sample from July 2005 to March 2012 in the estimation in comparison with the full sample from March 2000 to March 2012.

One particularly difficulty in dealing with Chinese trade data is that export and import values and volumes cannot be disentangled as Chinese government did not report price indexes for imports and exports, therefore proxies need to be used. Cheung et al. attempt to circumvent this difficulty by relying on several proxy measures includes PPI for finished goods [12], GLU-K indexes reported by Gaulier, Lemoine, and Unal-Kesenci, and Hong Kong unit value indexes. Among these proxies, GLU-K indexes have the drawback of being available only at the annual frequency while PPI and Hong Kong unit value indexes are both good proxies for imports. In this paper, Consumer price index (CPI) is used as a proxy for export prices to deflate Chinese exports. For import prices, I use Hong 
Kong unit value indexes as price deflator for Chinese imports.

Real effective exchange rate (REER) is calculated as followed and is drawn from IMF's international financial statistics.

$$
\operatorname{REER}=\prod_{i=1}^{N}\left(r e r_{i}\right)^{w_{i}}
$$

where $N$ denotes the number of currencies included in the index, $w_{i}$ stands for the weight of the $i^{\text {th }}$ currency and rer $_{i, t}$ represents the bilateral real exchange rate against each of China's trading partners 1 . In this method of measuring exchange rate, increase in Renminbi REER indicates appreciation while decrease in Renminbi REER implies depreciation.

Foreign demand is measured by world imports (Chinese imports excluded) and deflated by the global import price index collected from Bloomberg. For China's domestic demand, we take industrial production index (IPI) as proxy, and deflate it by the CPI. The Industrial Production Index (IPI) is an economic indicator used to measure the real production output of mining, manufacturing and utilities and it's collected from Bloomberg. I take industrial production as proxy instead of China's GDP for the reason that GDP is only available at a quarterly frequency.

Foreign direct investment (FDI) and value-added tax rebates (VAT rebates) are used as additional controls so as to avoid problem of omitted variables. FDI (actually utilized cumulative index) is obtained from Bloomberg and deflated by CPI. Value-added tax rebates (VAT rebates) returning to export companies is included because it can foster exports. FDI is introduced to both the export equation and the import equations and value-added tax rebates (VAT rebates) is included in export equation.

Finally, in each equation, i.e. trade balance equation, export equation and import equation, I include a deterministic trend when it is statistically significant. The deterministic trend is used to capture the on-going reforms in the Chinese economy and productivity improvements, which otherwise we cannot easily measure.

\section{Methodology}

In the estimation of trade balance equation, export equation and import equation, I apply co-integration techniques to determine whether a long-run relationship exists between Renminbi real effective exchange rate (REER) and the trade balance (TB), also between real effective exchange rate (REER) and exports and imports. Furthermore, if the long-run relationship exists, long-run price elasticities and income elasticities can be obtain by estimating trade balance equation and export, import equations.

\subsection{Stationary Test}

The first step is to conduct stationary tests to find the order of integration of the variables included in the equations. In this paper, Augmented Dickey-Fuller (ADF) test is applied for the existence of a unit root. 


\subsection{Co-Integration Test}

As integration of order one is established for the common components of the variables under investigation, the next step is to determine whether a long-run relationship exists. Co integration between the common components can be investigated using standard time serious tests such as the Johansen reduced rank approach (Johansen, 1995).

\subsection{Regression and Analysis}

The final step in the estimation is to estimate a regression of the lagged determinants and their differences through a non-linear least square approach for each equation.

\section{Results and Discussion}

In this paper, I conducted stationary test on variables which included in the trade balance equation, export equation and import equation. As a second step, Johansen procedure is applied to find co-integration vector for the series of variables. Finally, I ran regression on trade balance equation, export and import equations for both full sample, i.e. 2000.03-2012.03 and the sub-sample, from 2005.07 onwards. In the estimation of both samples, ordinary trade and processing trade are distinguished. In this section, the results of each test will be summarized, displayed and analyzed.

\subsection{Stationary Test Results}

Augmented Dickey-Fuller (ADF) test is conducted in this paper. Variables included in the trade balance equation, export and import equations in log difference are all tested for the existence of unit root. (See Table 1). For the full sample, in the trade balance equations, real effective exchange rate (LREER) and domestic demand (LDD) is I(1) while the other variables, including trade balance of

Table 1. Results of unit root test.

\begin{tabular}{|c|c|c|c|c|c|c|}
\hline \multirow{2}{*}{ Variables } & \multicolumn{3}{|c|}{ Full sample (2000-2012) } & \multicolumn{3}{|c|}{ Subsample (2005.07 onwards) } \\
\hline & Test stat. & Level of significant & conclusion & Test stat. & Level of significant & conclusion \\
\hline LREER & -8.72 & $1 \%$ & $\mathrm{I}(1)$ & -6.43 & $1 \%$ & $\mathrm{I}(1)$ \\
\hline LORTB & -2.87 & $10 \%$ & $\mathrm{I}(0)$ & -2.93 & $5 \%$ & $\mathrm{I}(0)$ \\
\hline LPROTB & -3.36 & $10 \%$ & $\mathrm{I}(0)$ & -3.83 & $5 \%$ & $\mathrm{I}(0)$ \\
\hline LFD & -3.50 & $5 \%$ & $\mathrm{I}(0)$ & -2.63 & $10 \%$ & $\mathrm{I}(0)$ \\
\hline LDD & -4.83 & $1 \%$ & $\mathrm{I}(1)$ & -2.77 & $10 \%$ & $\mathrm{I}(0)$ \\
\hline LFDI & -3.25 & $10 \%$ & $\mathrm{I}(0)$ & -2.18 & $5 \%$ & $\mathrm{I}(1)$ \\
\hline LOREX & -129.04 & $1 \%$ & $\mathrm{I}(2)$ & -1.64 & $10 \%$ & $\mathrm{I}(1)$ \\
\hline LPROEX & -3.10 & $5 \%$ & $\mathrm{I}(1)$ & -2.25 & $5 \%$ & $\mathrm{I}(1)$ \\
\hline LVATREBATE & -2.81 & $10 \%$ & $\mathrm{I}(0)$ & -3.83 & $5 \%$ & $\mathrm{I}(0)$ \\
\hline LORIM & -3.49 & $1 \%$ & $\mathrm{I}(1)$ & -2.23 & $5 \%$ & $\mathrm{I}(1)$ \\
\hline LPROIM & -1.74 & $10 \%$ & $\mathrm{I}(1)$ & -82.77 & $1 \%$ & $\mathrm{I}(2)$ \\
\hline
\end{tabular}


ordinary trade (LORTB), trade balance of processing trade (LPROTB), foreign demand (LFD) are all appeared to be stationary. In the export and import equations, ordinary exports (LOREX) is I(2), processing exports (LPEOEX) is I(1), control variables, i.e. foreign direct investment (FDI) and value-added tax rebates (VATREBATE) are stationary. Ordinary imports (LORIM) and processing imports (LPROIM) are both I(1).

For the subsample, in the trade balance equations, real effective exchange rate (LREER) is I(1) while the other variables, including trade balance of ordinary trade (LORTB), trade balance of processing trade (LPROTB), foreign demand (LFD) and domestic demand (LDD) are all appeared to be stationary. In the export and import equations, ordinary exports (LOREX), processing exports (LPROEX), processing imports (LPROIM) and foreign direct investment (FDI) are all I(1) while processing imports (LPROIM) is I(2) and value-added tax rebates (VATREBATE) is stationary.

As showed in the results of stationary test, the existence of unit root in the three cases cannot be rejected, therefore the next step is to determine whether co-integration relationships exist among the non-stationary variables. Co-integration between the common components can be investigated using standard time serious tests such as the Johansen reduced rank approach (Johansen, 1995).

\subsection{Co-Integration Results}

As showed in the results of stationary test, the existence of unit root in the three cases cannot be rejected, therefore the next step is to determine whether co-integration relationships exist among the non-stationary variables. Co-integration between the common components can be investigated using standard time serious tests such as the Johansen reduced rank approach (Johansen, 1995).

For the full sample, in the trade balance, LREER and LDD are found to be non-stationary series, therefore I ran Johansen test to examine if the co-integration relationship exists between these two variables. In the same vein, I ran Johansen test for non-stationary series, i.e. LREER, LOREX, LPROEX for the export equation, and LREER, LORIM, LPROIM, LDD for the import equation. Similarly, for the subsample, I ran Johansen test for LREER and LFDI in the trade balance equation, LREER, LOREX, LPROEX, LFDI in the export equation and finally LREER, LORIM, LPROIM, LFDI in the import equation (see Table 2).

For the full sample, I found 1 co-integrating vector between real effective exchange rate (LREER) and domestic demand (LDD) in the trade balance equation, another one in the export equation among real effective exchange rate (LREER), ordinary exports (LOREX) and processing exports (LPROEX), two co-integrating vector among real effective exchange rate (LREER), domestic demand (LDD), ordinary imports (LORIM), processing imports (LPROIM) in the import equation. For the subsample, one co-integrating vector is found for each group of non-stationary variables from trade balance equation, export and import equations. 
Table 2. Results of unrestricted co-integration rank test (trace test).

\begin{tabular}{|c|c|c|c|c|}
\hline Equations & Full sample (2000-2012) & Trace statistic & Critical value & $\begin{array}{l}\text { Hypothesized } \\
\text { No. of CE(s) }\end{array}$ \\
\hline TRADE BALANCE & LREER and LDD & 0.4911 & 3.8414 & $\begin{array}{l}\text { None* } \\
\text { at most } 1\end{array}$ \\
\hline EXPORT EQUATION & LREER, LOREX, LPROEX & 3.4962 & 15.4947 & $\begin{array}{l}\text { None }^{*} \\
\text { at most } 1\end{array}$ \\
\hline IMPORT EQUATION & LREER, LORIM, LPROIM, LDD & 5.1145 & 15.4947 & $\begin{array}{c}\text { None }^{*} \\
\text { at most } 1^{*} \\
\text { at most } 2\end{array}$ \\
\hline Equations & Subsample (2005.07 onwards) & Trace Statistic & Critical Value & $\begin{array}{l}\text { Hypothesized } \\
\text { No. of CE(s) }\end{array}$ \\
\hline TRADE BALANCE & LREER and LFDI & 0.6913 & 3.8414 & $\begin{array}{l}\text { None* } \\
\text { at most } 1\end{array}$ \\
\hline EXPORT EQUATION & LREER, LOREX, LPROEX, LFDI & 18.8848 & 29.7971 & $\begin{array}{l}\text { None } \\
\text { at most } 1\end{array}$ \\
\hline IMPORT EQUATION & LREER, LORIM, LPROIM, LFDI & 21.8175 & 29.7971 & $\begin{array}{c}\text { None }^{*} \\
\text { at most } 1\end{array}$ \\
\hline
\end{tabular}

${ }^{*}$ Trace test indicates $1 / 2$ co-integration equations at the 0.05 level. ${ }^{*} \mathrm{I}$ have used a Johansen co-integration test with the option intercept and trend in CE-no trend in VAR.

The co-integration test does not only indicate the existence of long-run relationship between real effective exchange rate and different types of exports and imports, but also, the finding of co-integrating vectors in each equations allows us to estimate a regression through a non-linear least square approach.

\subsection{Estimation Results}

The last procedure in the methodology is to run regressions on trade balance equation, export and import equations for the full sample, i.e. 2000.03-2012.03 and for the subsample, from 2005.07 onwards. In each case, I distinguish between ordinary and processing trade.

Firstly, the regression of trade balance equation give us a whole picture on the overall effect of Renmibi real effective exchange rate (REER) on both ordinary and processing trade balance.

As shown in Table 3, for the full sample from March 2000 to March 2012, Renminbi real effective exchange rate (LREER) has little influence on Chinese trade balance, neither for ordinary trade nor processing trade since the negative effect has found to be not statistically significant. Foreign direct investment (FDI) has small positive effect on trade balance and it's only statistically significant for ordinary trade. Interestingly, both foreign demand and domestic demand has opposite effect upon ordinary trade balance and processing trade balance. As expected, foreign demand has positive and significant effect on ordinary trade balance since ordinary exports respond positively to foreign demand (LFD), domestic demand has negative effect on ordinary trade balance as an increase in domestic demand would boost ordinary imports. However, the effect of foreign demand and domestic demand on processing trade balance is not with the expected sign and is relatively small. This result is in line with the idea that 
Table 3. Result of trade balance equation.

\begin{tabular}{ccccc}
\hline \multirow{2}{*}{ Variables } & \multicolumn{4}{c}{ Dependent variable } \\
\cline { 2 - 5 } & \multicolumn{2}{c}{ Full sample } & \multicolumn{2}{c}{ Subsample } \\
\cline { 2 - 5 } & $\begin{array}{c}\text { Ordinary trade } \\
\text { balance }\end{array}$ & $\begin{array}{c}\text { Processing trade } \\
\text { balance }\end{array}$ & $\begin{array}{c}\text { Ordinary trade } \\
\text { balance }\end{array}$ & $\begin{array}{c}\text { Processing trade } \\
\text { balance }\end{array}$ \\
\hline \multirow{2}{*}{ C } & -0.300218 & 2.538638 & 3.644332 & -1.260060 \\
& $(-0.257770)$ & $\left(4.051535^{* * *}\right)$ & $\left(2.304417^{* *}\right)$ & $(-1.112290)$ \\
LREER & -0.302212 & -0.026982 & -1.655933 & 0.661797 \\
LFD & $(-1.597939)$ & $(-0.265180)$ & $\left(-8.720253^{* * *}\right)$ & $\left(4.865134^{* * *}\right)$ \\
& 0.554739 & -0.885465 & 1.120039 & -0.547733 \\
LDD & $\left(3.246520^{* * *}\right)$ & $\left(-9.632174^{* * *}\right)$ & $\left(2.955842^{* * *}\right)$ & $\left(-2.017904^{* *}\right)$ \\
& -0.044052 & 0.072801 & -0.345880 & 0.185136 \\
LFDI & $(-1.144149)$ & $\left(3.514619^{* * *}\right)$ & $\left(-6.193919^{* * *}\right)$ & $\left(4.628226^{* * *}\right)$ \\
& 0.034450 & 0.003461 & 0.021051 & 0.002868 \\
R2 & $\left(2.635452^{* *}\right)$ & $(0.492178)$ & $(1.404312)$ & $(0.267066)$ \\
Adjust R2 & 0.185787 & 0.567141 & 0.604039 & 0.343263 \\
D.W. statistic & 0.162357 & 0.554685 & 0.583199 & 0.308698 \\
\hline
\end{tabular}

$\mathrm{t}$ statistics are displayed in the bracket, ${ }^{*}$ indicates significance at $10 \%$ level, ${ }^{* *}$ at $5 \%$ level and ${ }^{* * *}$ at $1 \%$ level.

processing trade is composed of processing exports and processing imports. Processing exports comprises exports of goods for assembly outside China and exports of products assembled using imported components while processing imports is comprised of the imports of components for assembly into exportables. That means processing exports might go hand in hand with domestic demand since increase in domestic demand would boost import, on the other hand, foreign demand might have positive effect on processing imports as foreign demand has positive impact on export and the processing imports comprises components for assembly into exportables.

For the subsample, i.e. from July 2005 onwards, I found higher and statistically significant negative effect on ordinary trade balance from Renminbi real effective exchange rate (LREER) which can be attributed to the reform of exchange rate regime started from July 2005. Chinese authority has announced a switch from the dollar peg regime to a managed floating exchange rate regime with reference to a basket of currencies based on market from July 2005, since when the volatility of Renminbi exchange rate increased and has greater impact on trade, especially for ordinary trade which refers to goods which are not subject to further processing and not assembled from imported components. However, the coefficient of REER is found to be positive and significant on the processing trade, this implies processing exports comprise larger proportion for assembly outside China and exports of goods assembled using imported components, therefore response the same way as ordinary imports to REER, while processing imports comprise imports of components for assembly into exportable therefore decrease with exports as REER goes up. Foreign demand (LFD) has positive coefficient on ordinary trade balance and negative coefficient on processing trade, domestic demand (LDD) has negative effect on ordinary trade balance 
and positive effect on processing trade balance, both have same signs as I found in full sample. Foreign direct investment (LFDI) still has little effect on both ordinary and processing trade balance since the coefficients are not statistically significant.

Then I ran regressions on export and import equations in further to discover the impact of Renminbi real effective exchange rate (REER) on export and import respectively, as always, I distinguished between ordinary and processing exports and imports.

As shown in Table 4, for the full sample, Renimibi real effective exchange rate (LREER) has negative and effect on both ordinary and processing exports as expected, while the effect on ordinary exports has found to be statistically insignificant. The coefficients of foreign demand (LFD) are found positive and significant in both cases as an increase in foreign demand would boost exports. As for the control variables, value-added tax rebate (VATREBATE) and Foreign direct investment (LFDI) are found highly significant and with the expected sign. VATREBATE has positive impact on exports as it fosters exports by returning tax to export companies. FDI has positive effect on exports since foreign direct investment is geared towards the export industry.

For the subsample, the coefficient of Renminbi exchange rate has grown tremendously for both ordinary and processing exports while still insignificant for ordinary exports. As for foreign demand (LFD), I found positive coefficient on ordinary exports and negative coefficient on processing exports but both of them are not statistically significant which implies the fact that Chinese exports depend less on foreign demand since the new exchange rate was carried out from July 2005. For control variables, VATREBATE and FDI are both found significant and with the expected sign, the coefficients of these two controls are almost even between ordinary exports and processing exports.

Table 4. Result of export equation.

\begin{tabular}{|c|c|c|c|c|}
\hline \multirow{3}{*}{ Variables } & \multicolumn{4}{|c|}{ Dependent variables } \\
\hline & \multicolumn{2}{|c|}{ Full sample } & \multicolumn{2}{|c|}{ Subsample } \\
\hline & Ordinary exports & Processing exports & Ordinary exports & Processing exports \\
\hline $\mathrm{C}$ & $\begin{array}{c}4.525107 \\
\left(2.007187^{\star \star}\right)\end{array}$ & $\begin{array}{c}3.088918 \\
\left(1.911786^{\star}\right)\end{array}$ & $\begin{array}{c}6.893703 \\
(0.560200)\end{array}$ & $\begin{array}{c}21.69102 \\
(1.637122)\end{array}$ \\
\hline LREER & $\begin{array}{c}-0.385679 \\
(-1.159730)\end{array}$ & $\begin{array}{c}-1.276276 \\
\left(-5.354877^{\star * *}\right)\end{array}$ & $\begin{array}{c}-1.653554 \\
(-1.090865)\end{array}$ & $\begin{array}{c}-4.114242 \\
\left(-2.520886^{\star *}\right)\end{array}$ \\
\hline LFD & $\begin{array}{c}0.750532 \\
\left(-1.841141^{\star}\right)\end{array}$ & $\begin{array}{c}0.719392 \\
\left(2.462392^{\star *}\right)\end{array}$ & $\begin{array}{c}0.132580 \\
(0.048560)\end{array}$ & $\begin{array}{c}-1.710894 \\
(-0.582011)\end{array}$ \\
\hline LVATREBATE & $\begin{array}{c}0.274022 \\
\left(10.62125^{\star \star *}\right)\end{array}$ & $\begin{array}{c}0.147207 \\
\left(7.961437^{\star \star \star}\right)\end{array}$ & $\begin{array}{c}0.638526 \\
\left(2.098798^{\star *}\right)\end{array}$ & $\begin{array}{c}0.606956 \\
\left(1.852933^{\star}\right)\end{array}$ \\
\hline LFDI & $\begin{array}{c}1.000619 \\
\left(36.13018^{\star * *}\right)\end{array}$ & $\begin{array}{c}1.017300 \\
\left(51.25358^{\star * *}\right)\end{array}$ & $\begin{array}{c}0.521055 \\
\left(4.722793^{* * *}\right)\end{array}$ & $\begin{array}{c}0.488476 \\
\left(4.112152^{\star * *}\right)\end{array}$ \\
\hline $\mathrm{R} 2$ & 0.934748 & 0.958760 & 0.275736 & 0.251819 \\
\hline Adjust R2 & 0.932771 & 0.957510 & 0.233132 & 0.207808 \\
\hline D.W. statistic & 0.602348 & 0.555774 & 1.811235 & 1.822269 \\
\hline
\end{tabular}

$\mathrm{t}$ statistics are displayed in the bracket, ${ }^{*}$ indicates significance at $10 \%$ level, ${ }^{* *}$ at $5 \%$ level and ${ }^{* *}$ at $1 \%$ level. 
In China's case, the expected sign for the effect on imports from Renminbi's real effective exchange rate is less clear. Generally, if the gained purchasing power is greater than the reduced demand due to the associated fall in exports, a real appreciation of Renminbi should promote imports.

For the full sample, see Table 5, the coefficients of Reminbi real effective exchange rate (LREER) and domestic demand (LDD) for ordinary imports are consistent with expected principle. A rise in real effective exchange rate (LREER) and domestic demand (LDD) will both promote ordinary imports. However, the situation for the other type of imports is on the contrary. The negative coefficient of real effective exchange rate (LREER) implies the particular composition of processing imports. Different from ordinary imports, processing imports comprises of components for assembly into exportable. Therefore, affected by export trade, processing imports vary in the opposite way with ordinary imports, a Renmibi appreciation would lead to reduction in processing imports. The effect on processing imports from domestic demand is not statistically significant for the similar reason mentioned above. FDI, as control variable, have positive and highly significant effect on both types of imports.

For the subsample, I notice all the signs are in consistent with the ones found in the full sample but just a few of the coefficients are statistically significant. Renimibi exchange rate has insignificant effect on ordinary imports but significant and negative effect on processing imports, this implies that Renminbi appreciation has more to do with exports than imports after the new exchange rate regime was carried out since July 2005, therefore greater impact on processing imports which are export-related. I also found that the effect on processing imports became larger than that in the full sample, this can be explained by the reform of exchange rate regime I discussed previously. As for domestic demand, the effect on both types of imports is not statistically significant which indicates that imports do not depend much on domestic demand from July 2005 and the

Table 5. Result of import equation.

\begin{tabular}{ccccc}
\hline \multirow{2}{*}{ Variables } & \multicolumn{3}{c}{ Dependent variables } \\
\cline { 2 - 4 } & Oull sample & \multicolumn{2}{c}{ Subsample } \\
\cline { 2 - 4 } Crdinary imports & Processing imports & Ordinary imports & Processing imports \\
\hline LREER & -4.402227 & 10.73444 & -4.363266 & 16.13707 \\
& $\left(-2.485496^{* *}\right)$ & $\left(11.02233^{* * *}\right)$ & $(-0.792790)$ & $\left(2.940725^{* * *}\right)$ \\
LDD & 1.473299 & -2.383799 & 1.675906 & -3.442143 \\
& $\left(3.594884^{* * *}\right)$ & $\left(-10.57833^{* * *}\right)$ & $(1.274790)$ & $\left(-2.62604^{* * *}\right)$ \\
LFDI & 0.402990 & -0.080306 & 0.528942 & -0.057558 \\
R2 & $\left(4.264724^{* * *}\right)$ & $(-1.545611)$ & $(1.291226)$ & $(-0.140923)$ \\
Adjust R2 & 1.057041 & 0.985843 & 0.497083 & 0.476230 \\
D.W. statistic & $\left.0.41 .22388^{* * *}\right)$ & $\left(52.96104^{* * *}\right)$ & $\left(4.573963^{* * *}\right)$ & $\left(4.395058^{* * *}\right)$ \\
\hline
\end{tabular}

t statistics are displayed in the bracket, ${ }^{*}$ indicates significance at $10 \%$ level, ${ }^{* *}$ at $5 \%$ level and ${ }^{* *}$ at $1 \%$ level. 
income elasticity has become insignificant since then. FDI still has positive and highly significant impact on fostering imports, while less powerful after the reform of exchange rate regime.

\section{Conclusions}

By estimating trade balance equation, export and import equations, this paper offers several findings concerning the impact of Renminbi appreciation on China's trade balance. First, the negative effect on China's trade balance from Renminbi Appreciation is not significant from 2000 to 2012, and China's trade surplus mainly replies on foreign demand. However, after the new exchange rate regime (Chinese government switched the exchange rate regime from the dollar peg to a managed floating exchange rate regime base on market supply and demand with reference to a basket of currencies on 21 July, 2005) was carried out, Chinese trade balance becomes very sensitive to fluctuations in the real effective exchange rate, specifically, the ordinary trade balance response negatively to Renminbi appreciation while processing trade balance response positively to it. Secondly, for exports, I found the Renminbi's real effective exchange rate had most of its influence on processing exports than ordinary exports, and the price elasticity for processing exports becomes larger in the period during the new exchange rate regime when Renminbi has been floating more frequently. This result indicates Renminbi appreciation would reduce exports, particularly processing exports. Thirdly, for imports, real effective exchange rate has positive impact on ordinary imports and negative effect on processing imports, but the Renminbi appreciation since July 2005 affect mainly the processing imports in reducing it.

In summary, this paper shows empirically that Renmibi appreciation has little impact on China's trade balance in the long period from 2000 to 2012, however, the effect in the period from 2005 to 2012 has found to be significant. Specifically, the appreciation in Renminbi has found to reduce ordinary trade balance and increase processing trade balance. In addition, the appreciation has larger impact on processing trade (both the processing exports and the processing imports) than it has on ordinary trade. Therefore, I still can't provide final conclusion to the issue that whether the appreciation in Renminbi reduces China's trade surplus and correct global imbalance. The answer depends on whether the reduction in ordinary trade balance caused by appreciation exceeds the increase in processing trade balance, if it does, the result essentially illustrates that appreciation in Renminbi can help to solve the trade surplus. However, I still hold the view that exchange rate policy alone is not enough to solve China's trade balance and global imbalance since the impact on exports and imports from real effective exchange is not statistically significant in many cases.

There exist several limitations in this paper: firstly, the use of proxies for import and export price in the model might lessen the accuracy of results from my estimations; secondly, the analysis in China's trade balance is not comprehensive enough as bilateral trade estimations are not included in the model; finally, no 
further estimations on the exact impact from Renminbi appreciation on ordinary trade and processing trade are provided to give answer to the question that whether appreciation in Renminbi can correct trade surplus and solve global imbalance.

\section{Fund}

This study was funded by Guangdong University of Finance-2017 ChuangXinQiangXiao Project.

\section{References}

[1] Garcia-Herrero, A. and Tuuli, K. (2007) Can the Chinese Trade Surplus Be Reduced through Exchange Rate Policy? BOFIT Discussion Paper 2007(6).

[2] Dees, S. (2001) The Real Exchange Rate and Types of Trade: Heterogeneity of Trade Behaviours in China. Paper Presented at the Workshop on China's Economy Organised by the CEPII in December 2001.

[3] Benassy-Quere, A. and Lahreche-Revil, A. (2003) Trade Linkages and Exchange Rates in Asia: The Role of China. CEPII Working paper No. 2003-21.

[4] Thorbecke, W. (2006) The Effect of Exchange Rate Changes on Trade in East Asia. RIETI Discussion Paper Series, 06-E-009.

[5] Shu, C. and Yip, R. (2006) Impact of Exchange Rate Movements on the Chinese Economy, Hong Kong Monetary Authority, No. 3/06, July 2006.

[6] Marquez, J. and Schindler, J.W. (2006) Exchange-Rate Effects on China's Trade: An Interim Report. Board of Governors of the Federal Reserve System. International Finance Discussion Papers No. 861. https://doi.org/10.2139/ssrn.906854

[7] Whalley, J. and Wang, L. (2011) The impacts of Renminbi Appreciation on Trade Flows and Reserve Accumulation in a Monetary Trade Model. Economic Modelling, 28, 614-621. https://doi.org/10.1016/j.econmod.2010.06.010

[8] Chee-Wooi, H., Siong-Hook, L., Tze-Haw, C. (2015) The Impact of the Renminbi Real Exchange Rate on ASEAN Disaggregated Exports to China. Economic Modelling, 47, 253-259. https://doi.org/10.1016/j.econmod.2015.02.025

[9] Cerra, V. and Saxena, S.C. (2003) How Responsive Is Chinese Export Supply to Market Signals? China Economic Review, 14, 350-370. https://doi.org/10.1016/j.chieco.2003.08.002

[10] Mann, C. and Plück, K. (2005) The U.S. Trade Deficit: A Disaggregated Perspective. Institute for International Economics Working Paper WP 05-11, Institute for International Economics, Washington DC.

[11] Eckaus, R.S. (2004) Should China Appreciate the Yuan. MIT Working Paper 04-16. https://doi.org/10.2139/ssrn.527902

[12] Cheung, Y.W., Chinn, M.D. and Fujii, E. (2007) The Overvaluation of Renminbi Undervaluation. Journal of International Money and Finance, 26, 762-785. https://doi.org/10.1016/j.jimonfin.2007.04.005

[13] McKinnon, R.I. (2005) China's New Exchange Rate Policy: Will China Follow Japan into a Liquidity Trap? Weekly Economist, 50, 1-13.

[14] Zhang, Z.Y. and Sato, K. (2012) New Estimates of the Equilibrium Exchange Rate: The Case for the Chinese Renminbi. The World Economy (2012).

[15] Gong, C. and Liu, Z.-Y. (2015) The Effects of the RMB's Appreciation on Trade Balance in US. Journal of the Korea Society of Computer and Information, 20, 135-142. https://doi.org/10.9708/jksci.2015.20.11.135 
Submit or recommend next manuscript to SCIRP and we will provide best service for you:

Accepting pre-submission inquiries through Email, Facebook, LinkedIn, Twitter, etc. A wide selection of journals (inclusive of 9 subjects, more than 200 journals)

Providing 24-hour high-quality service

User-friendly online submission system

Fair and swift peer-review system

Efficient typesetting and proofreading procedure

Display of the result of downloads and visits, as well as the number of cited articles Maximum dissemination of your research work

Submit your manuscript at: http://papersubmission.scirp.org/

Or contact ajibm@scirp.org 